Јована Вулић*

Самостални истраживач
821.134(7/8).09-32 Карпентјер А. https://doi.org/10.18485/ai_lik.2018.4.6.5 оригинални научни рад

\title{
ВРЕМЕ И ВЕЧНОСТ У ПРИПОВЕЦИ „ПУТ КА СЕМЕНУ“ АЛЕХА КАРПЕНТЈЕРА
}

Алехо Карпентјер у свом делу „Пут ка семену“ обрађује универзалну тему времена и вечности кроз призму митолошког контекста. Поступком приповедања уназад представљен је људски живот од тренутка смрти све до момента зачећа. Карпентјер испитује борбу између линеарног историјског и митолошког цикличног времена и поставља питање постојања временских категорија прошлости, садашњости и будућности. „Пут ка семену“ нам приказује пут ка вечности који почиње након краја овоземаљског времена, у тренутку када се човек сети својих корена.

Кључне речи: Алехо Карпентјер, „Пут ка семену“, време, вечност, мит, приповедање уназад, циклично време.

Сви смо ми семе и йойомсииво вечносиии. Бјорнстјерне Бјорнсон

Једна од најплоднијих тема у стваралаштву Алеха Карпентјера (Alejo Carpentier), истакнутог кубанског писца $\mathrm{XX}$ века, несумњиво је тема времена и вечности. Читава збирка приповедака овог аутора под називом Борба времена (Guerra del tiempo, 1958) посвећена је проучавању различитих перспектива времена, а међу тим приповеткама налази се и дело „Пут ка семену“ („Viaje a la semilla“) објављено први пут још 1944. године. Занимљиво је да Карпентјер мотив времена ставља у контекст мита и на овај начин додаје нову димензију посматрања концепта времена. Такав поступак

* jovana.vulic.bg@gmail.com 
приметан је и у приповеци „Пут ка семену“ где се митолошко циклично време преплиће са историјским линеарним временом у тежњи да се искаже комплексна темпорална димензија стварности. Карпентјерова иновативност у приказу времена различитим техникама и методама огледа се и у чињеници да његова концепција времена трансцендира строго схваћене границе књижевног дела. Битно је истаћи да ово дело настаје у периоду у ком Карпентјер још увек није био изнео своју теорију о чудесном реализму, али анализом садржаја текста уочавамо да приповетка представља нацрт по коме ће се касније ова теорија формирати.

У раду Румеларе (Rommelaere 2009: 28) наилазимо на став да Карпентјер у свом стваралаштву посвећује највише пажње теми „eterno retorno“1 коју развија кроз биографију маркиза Капељанијаса (Capellanías). Гонсалес Ернандес (González Hernández 2017: 8) објашњава ток радње ове приповетке:

El relato "Viaje a la semilla" (1944) comprime en un cuento toda la vida de don Marcial, Marqués de Capellanías, con la peculiaridad de que la narración comienza con el día de su muerte y a medida que avanza la historia, recorre todas las etapas de su vida hasta llegar al momento de la gestación, de ahí el título del cuento, viaje a la "semilla", al origen, a lo primigenio. Al transcurrir el tiempo de atrás hacia delante, también las etapas de maduración del protagonista van decayendo, hasta el punto de encontrarse en el vientre materno. ${ }^{2}$

Тема вечног повратка организована је у тринаест поглавља. Регресивно време уочава се, међутим, само у централним поглављима (II-XII). Такав поступак никако се не може сматрати случајним јер се на тај начин време повратка у прошлост приказује унутар циклуса који почиње првим

1 „вечни повратак“ Сви преводи су ауторски осим када је другачије назначено.

2 „Приповетка 'Пут ка семену' (1944) сажима у једну причу цео живот дон Марсијала, маркиза Капељанијаса са специфичном нарацијом која почиње са даном његове смрти и како одмиче прича тако се смењују етапе његовог живота до тренутка зачећа, одатле потиче наслов, пут ка 'семену', пореклу, ономе што је било првобитно. Како време протиче од позади ка напред, тако етапе сазревања опадају све док се не нађе у мајчиној утроби“. 
поглављем, а завршава се тринаестим, на истом месту где је радња почела. (Altenberg 2007: 3)

\section{Улога приповедача}

Карпентјер несумњиво користи технику приповедања уназад, али то сазнање не расветљава све наративне аспекте „Пута ка семену“. Једно од суштинских питања односи се на могућност постојања само једног приповедача који једноставно одлучује да обрне след догађаја, или два приповедача који формирају више временских и просторних димензија.

Карпентјер комбинује свезнајућег приповедача и приповедача у улози сведока догађања који користи субјективну перспективу. Да је Карпентјер своје приповедање свео само на свезнајућег приповедача, живот дон Марсијала (don Marcial) не би ни по чему био посебан ни магичан. Међутим, увођењем субјективног приповедача-сведока у дело, резултат постаје поново проживљени живот који наступа после смрти.

En "Viaje a la semilla", con todo, no se produce una simple alteración de los acontecimientos por parte del narrador. No se trata tan sólo de que don Marcial haya vivido su vida y el narrador la presente al revés, comenzando por la muerte y avanzando hacia el nacimiento. Por el contrario, don Marcial vuelve a vivir su vida hacia atrás después de muerto, por lo que el narrador respeta en lo esencial el orden de los acontecimientos de la historia. ${ }^{3}$ (Martín Jiménez 1994: 316).

Потребно је нагласити да прича о животу дон Марсијала не почиње његовом смрћу, већ тренутком у коме радници руше маркизову вилу у којој је провео цео живот, да би се завршила не тренутком зачећа маркиза у утроби мајке, већ описом природе која се такође враћа у првобитно стање. За овакав приказ радње неопходан је свезнајући приповедач,

3 „У 'Путу ка семену', не долази до обичне замене тока догађаја од стране наратора. Не ради се само о томе да је дон Марсијал живео живот а приповедач га приказао уназад почевши од смрти и крећући се ка рођењу. Насупрот овоме, дон Марсијал поново проживљава свој живот уназад, након смрти, што приповедач поштује тако што оставља основни распоред догађања у причи.“” 
неко ко је изнад времена, ко није само маркизов савременик и сведок његовог живота, већ неко ко разуме законе природе и порекло свега земаљског. Свезнајући приповедач, дакле, описује повратак природе својим коренима, док приповедач-сведок говори о животу дон Марсијала од тренутка његове смрти па до детињства. Када смо утврдили постојање два приповедача, можемо говорити о два различита протока времена, па тако примећујемо да се време приповедања убрзава сваки пут када се описује промена стања предмета или ствари.

"Los cuadrados de mármol, blancos y negros volaron a los pisos, vistiendo la tierra. Las piedras con saltos certeros, fueron a cerrar los boquetes de las murallas. Hojas de nogal claveteadas se encajaron en sus marcos, mientras los tornillos de las charnelas volvían a hundirse en sus hoyos, con rápida rotación. En los canteros muertos, levantadas por el esfuerzo de las flores, las tejas juntaron sus fragmentos, alzando un sonoro torbellino de barro, para caer en lluvia sobre la armadura del techo. La casa creció, traída nuevamente a sus proporciones habituales, pudorosa y vestida. La Ceres fue menos gris. Hubo más peces en la fuente. Y el murmullo del agua llamó begonias olvidadas. /.../Los cirios crecieron lentamente, perdiendo sudores. /.../ Las mechas blanquearon, arrojando el pabilo. /.../Confusas y revueltas, las vigas del techo se iban colocando en su lugar. Los pomos de medicina, las borlas de damasco, el escapulario de la cabecera, los daguerrotipos, las palmas de la reja, salieron de sus nieblas. /.../ Ya brillaban, muy claras, las arañas del gran salón. Las grietas de la fachada se iban cerrando. El piano regresó al clavicordio. Las palmas perdían anillos. Las enredaderas saltaban la primera cornisa. Blanquearon las ojeras de la Ceres y los capiteles parecieron recién tallados. /.../ Los muebles crecían./.../ Los armarios de cornisas labradas ensanchaban el frontis./.../ Las butacas eran más hondas y los sillones de mecedora tenían tendencia a irse para atrás. /.../ Cuando los muebles crecieron un poco más /.../ Las aves volvieron al huevo en torbellino de plumas. Los peces cuajaron la hueva, dejando una nevada de escamas en el fondo del estanque. Las palmas doblaron las pencas, desapareciendo en la tierra como abanicos cerrados. Los tallos sorbían sus hojas y el suelo tiraba de todo lo que le perteneciera. El trueno retumbaba en los corredores. Crecían pelos en la gamuza de los guantes. Las mantas de lana se destejían, redondeando el vellón de carneros distantes. Los armarios, los vargueños, las camas, 
los crucifijos, las mesas, las persianas, salieron volando en la noche, buscando sus antiguas raíces al pie de las selvas. Todo lo que tuviera clavos se desmoronaba. Un bergantín, anclado no se sabía dónde, llevó presurosamente a Italia los mármoles del piso y de la fuente. Las panoplias, los herrajes, las llaves, las cazuelas de cobre, los bocados de las cuadras, se derretían, engrosando un río de metal que galerías sin techo canalizaban hacia la tierra. Todo se metamorfoseaba, regresando a la condición primera. El barro, volvió al barro, dejando un yermo en lugar de la casa." ${ }^{4}$ (Carpentier 2001:45-62).

4 „Четвртасти блокови црног и белог мермера полетеше на спратове, облачећи земљу. Каменови, сигурним кораком учинише да нарасту зидови. Оковани листови ораха утиснуше се у своје оквире док се шрафови шарки брзим окретањем уврнуше у своје рупе. По мртвим травњацима црепови саставише своје крајеве подижући шуман вртлог блата, да би као киша пали на арматуру крова. Кућа је нарасла, поново доведена у своје уобичајене размере, стидљива и обучена. Церес постаде мање сива. Би више риба у језерцету. А шапат извора позва заборављене бегоније. /.../ Свеће полако нарастоше, преставши да капљу. /.../ фитиљи побелеше одбацивши огореле крајеве. /.../ Помешане и испретуране, греде таванице су се полако враћале на своја места. Флашице са лековима, ресе од дамаста, перваз око узглавља, бакрорези и палме са решеткама изађоше из измаглице. /.../ Већ су се блистали лустери у великом салону. Пукотине на фасади су се затварале. Клавир се претворио у клавсен. Палме су губиле прстенове. Пузавице су стизале до пераза на првом спрату. Побелеше подочњаци богиње Церес а стубови се учинише свеже исклесани. /.../ Намештај је растао./.../ Ормани са изрезбареним ивицама су се ширили. /.../ Фотеље су биле дубље а столице за љуљање су се много више нагињале уназад./.../ Када је намештај још мало порастао /.../ У вихору перја, птице се вратише у јаја. Рибе се претворише у икру, остављајући за собом облак крљушти у рибњаку. Палме скупише своје велике листове и нестадоше у земљи као склопљене лепезе. Стабла и гране су ублачили своје листове а земља је вукла све што јој је припадало. Гром је одјекивао по ходицима. Расле су длаке на кожи рукавица. Вунени покривачи су се парали попуњавајући руна далеких оваца. Ормани, комоде, кревети, распећа, столови, жалузине, одлетеше у ноћ тражећи своје старе коренове у подножју шума. Све што је имало ексере распадало се. Један теретни брод, укотвљен ко зна где, ужурбано је однео мермер са подова и из фонтане. Оружје и оклопи, гвожђурија, кључеви, бакарне посуде, демови из коњушњица топили су се уливајући се у реку метала која се разним каналима сливала у земљу. Све се преображио у свој првобитни облик. Блато се вратило блату остављајући пустару на месту где је била кућа.“ (Карпентјер 2011: 125-140) 
Претходни пример смо обликовали изузимајући из приче све што се тиче живота дон Марсијала, и тако смо стигли до закључка да „Пут ка семену“ није само прича о човеку који се враћа свом пореклу. Тема „Пута ка семену“ много је универзалнија, толико да можемо рећи да је реч о алузији на библијску причу о Постању. Ова библијска прича приповеда како је Бог прво створио природу, па тек онда човека. Вративши се тако уназад порекло човека не завршава се зачећем појединачног људског бића већ Постањем. По хришћанској догми, наш живот не започиње зачећем, већ стварањем првог човека кроз кога касније настаје свако појединачно људско биће.

Уколико се вратимо времену о коме говори свезнајући приповедач, увиђамо да је реч о Историји целокупног човечанства, времену које обухвата векове и миленијуме. Румеларе (Rommelaere 2009: 50) ово потврђује у свом истраживању: „/.../ es la corporización de su mirada cósmica, que entrecruza lo temporal y lo intemporal, lo concreto y lo arquetípico, un momento y toda la Historia“. 5 Управо из овог разлога Карпентјеру је био потребан свезнајући и свеприсутни приповедач који је ту од Постања времена. Са друге стране, нарација приповедача-сведока обухвата много мањи временски период - један људски век.

Док свезнајући приповедач убрзава време тиме што користи једноставну синтаксу, свршена глаголска времена и систем набрајања, те изоставља непотребне описе, када на ред дође приповедање маркизовог живота, радња и време се успоравају. Износе се бројни биографски елементи живота дон Марсијала, допуњени описима његовог физичког и психичког стања. На овај начин Карпентјер час убрзава, час успорава проток времена, постижући на овај начин динамичну атмосферу приповетке. Ако изузмемо поступак убрзавања, радња дела тече без било каквих измена, по обрнутом хронолошком редоследу, односно Алтенберговим (Altenberg 2007: 2) речима: „Resulta incluso ser una narración

5 „/.../ његово стварање космичке перспективе је заслужно за спој пролазног и непролазног, конкретног и архетипског, једног тренутка и читаве историје“ 
bastante convencional sin anacronías ni otras particularidades discursivas que llamen la atención“6.

\section{2. Реверзибилност времена (приповедање уназад)}

Поступком приповедања уназад Карпентјер нам кроз биографију маркиза Капељанијаса указује на блискост која постоји између првих и последњих тренутака људског живота, док Румеларе (Rommelaere 2009: 33) Карпентјеров поступак реверзибилности објашњава речима: „de esta manera embarca lo que hay entre la nada y la nada. ${ }^{\text {"7 }}$ Карпентјер на овај начин жели да пружи читаоцима паралелу између рођења и смрти, догађаја који, као што видимо из дела, наликују један на други: човек након смрти прелази у неки облик небића, као што пре рођења исто тако представља небиће. Међутим, можемо се запитати колико тачно траје путовање од смрти до зачећа. Мартин Хименес (Martín Jiménez 1994: 319) дао је следећи одговор: „El proceso en el que se desarrolla en sentido inverso la vida del protagonista transcurre en el corto espacio de una noche del tiempo real. “8 Ипак, чини се немогућим да се људски век може сместити у једну ноћ. То би значило да смо ми као човечанство у заблуди да наш живот траје много дуже него што то стварно јесте, те бројимо године и месеце, а заправо имамо на располагању нешто мање од дванаест сати у овом свету. Намеће се питање зашто је ноћ та која означава живот човека, посебно имајући у виду уобичајено виђење да је живот човека као најсавршенијег бића светла тачка овога света, а не тама и помрачина. Све ово Карпентјер приказује кроз биографију једног маркиза, уважене личности, а не обичног човека.

Радња дела обухвата један затворени простор, маркизову вилу и њену ближу околину, што доприноси утиску о

6 „Произилази да је приповедање чак доста уобичајено без анахронија и осталих дискурсивних особености које би привукле пажњу.“

7 „на овај начин приказује оно што се налази између ничега и ничега.“

8 „Процес у којем се развија обрнутом смислу живот протагонисте протиче у кратком временском периоду од једне ноћи стварног времена.“ 
краткоћи и сведености људског живота (Martín Jiménez 1994: 325). Ово ограничено и кратко време људског века најбоље можемо сагледати у речима: „Пробудили су се из небића и поново утонули у сан“ (Карелин 2014: 16). Карпентјер (Carpentier 2001: 61) сликовито наглашава да је на нашем рођењу присутна и смрт: „Entonces cerró los ojos que sólo divisaban gigantes nebulosos y penetró en un cuerpo caliente, húmedo, lleno de tinieblas, que moría." Овај сегмент, иако на први поглед не изгледа тако јер је у питању реверзибилност догађаја, истовремено представља рођење маркиза и смрт његове мајке. Отуда јасно видимо Карпентјерову намеру да споји смрт и рођење не само у спољашњој структури текста, већ и у појединим епизодама биографије дон Марсијала. Ову приповедачку слику можемо проширити Карелиновим (2014: 26) виђењем човека: „Умирао је од првог дана свог рођења“. Посматрајући ову тврдњу постављамо питање на које ћемо се вратити на самом крају рада: Ако кретањем од рођења ка смрти умиремо, да ли то значи да вративши се уназад од смрти ка рођењу заправо живимо?

Очигледно је да реверзибилност времена поништава смрт и поново оживљава маркиза, али питамо се из ког је разлога Карпентјер применио тај поступак. Враћајући време уназад Карпентјер не само да поништава смрт, већ и тежи потпуном ослобађању човека од друштвених норми и свођењу на његову првобитну природу. Карпентјер мотив поновног стицања слободе до те мере вешто укључује у радњу дела да то читаоцу личи на потпуно природан процес: „La Marquesa trocó su vestido de viaje por un traje de novia, y, como era costumbre, los esposos fueron a la iglesia para recobrar su libertad“10 (Carpentier 2001: 51). Маркиз, дакле, током реверзибилности времена излази из цркве слободан, као што је једном раније изашао из цркве као ожењен човек.

9 „Онда је затворио очи, које су само разликовале магловите џинове, и утиснуо се у једно топло, влажно и мрачно тело које је умирало.“ (Карпентјер 2011: 139)

10 „Маркиза је своје одело за пут заменила невестинском хаљином, и по обичају, супружници су отишли у цркву да би поново постали слободни.“ (Карпентјер 2011: 130) 
Још један пример налазимо у титули коју аутор додаје лику Марсијала. Карпентјер назива Марсијала маркизом од тренутка његове смрти, па све до поглавља у ком је Марсијал поново постао адолесцент. Од тог тренутра Карпентјер одбацује титулу главног лика и просто га зове само именом. (González Hernández 2017: 11). Јасно видимо ауторову намеру да и на овај начин ослободи свог протагонисту друштвених формалности, и закључујемо да повратак уназад служи да би се човек ослободио свог пређашњег живота и ушао у нови живот потпуно очишћен и ослобођен од свега земаљског.

\section{3. Књижевни лик као покретач реверзибилности времена}

Чини се да Карпентјеру нису довољни само приповедачи како би реверзибилношћу времена приповедања ослободио човека од свог пређашњег живота, већ у те сврхе користи и једног од ликова у приповеци. Тренутак у коме време креће уназад означен је присуством старог црнца: „Entonces el negro viejo, que no se había movido, hizo gestos extraños, volteando su cayado sobre un cementerio de baldosas. /.../El viejo introdujo una llave en la cerradura de la puerta principal, y comenzó a abrir

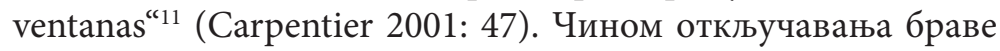
Карпентјер нам отвара врата новог универзума, света где је све наопачке и тежи својим коренима. Међутим, намеће се питање зашто је Карпентјеру био потребан старац, и то црне пути, да би подстакао кретање времена уназад. Лик црнца представља спону између магије и стварности. Гонсалес Ернандес (González Hernández 2017: 9) објашњава улогу овог лика: „No puede pasarse por alto, por tanto, la utilización del realismo mágico, que supone una conexión entre la realidad y la fantasía del relato. Para ello, Carpentier toma como apoyo la reversibilidad del tiempo, que es encarnada por el negro viejo “. ${ }^{2}$

11 „Тада црни старац, који се није био померио, поче да прави чудне покрете, бацивши свој штап на гробље од керамичких плочица./.../ Старац завуче кључ у браву главних врата, а затим поче да отвара прозоре.“ (Карпентјер 2011: 126)

12 „Због тога се не може занемарити употреба магичног реализ- 
Лик црнца отелотворава жељу аутора да задржи веродостојност тиме што његовим стварањем повезује стварност и магију (González Hernández 2017: 9). Постоји, међутим, још један разлог који оправдава ауторову одлуку да уведе лик црнца јер појавом старог црнца писац у ствари алудира на утицај афроамеричке митологије и магијских веровања присутан на Куби и у XX веку. Луис (Luis 1991: 155) допуњава ову тврдњу речима: „Obviamente, el negro viejo es un cura de una religión africana. "13. Исти аутор (Luis 1991: 155) додаје да „Пут ка семену“ заједно са Карпентјеровим делом Кратевстиво овог светй (El Reino de este mundo) чини спој европске и афричке перспективе стварности. Овакав спој најбоље илуструје пример из романа Кральевстиво овоі свети а када Макандалово (Makandal) спаљивање белци виде као смрт, док црнци у том истом догађају виде почетак новог живота (Luis 1991: 153). На исти начин у „Путу ка семену“ радници не осећају проток времена уназад, док управо стари црнац симболише магију која обрће временски проток. Гонсалес Ернандес (González Hernández 2017: 9) користи интересантан назив да означи улогу црнца у причи: „el testigo del tiempo“"14.

Занимљиво је да Карпентјер спомиње старог црнца само на почетку приче и да се ту завршава његова улога. Непознат нам је чак и његов идентитет, што је посебно необично имајући у виду да је његово присуство у делу нужно како би време променило свој правац (Altenberg 2007: 16). Верујемо, пак, да у Карпентјеровом делу ништа није случајно, те да се аутор на овај начин игра са читаоцима јер нам саิм аутор, можда ипак открива идентитет старог црнца, премда не експлицитно. Bећ у IX поглављу у ком пролазимо кроз Марсијалово детињство, увиђамо појаву једног новог лика који је у том периоду био веома битан за протагонисту дела: „Tuvo ganas de llorar, pero en ese momento apareció el

ма који подразумева везу између стварности и фикције приче. Карпентјер као средство за повезивање узима повратак времена који је отелотворен кроз лик старог црнца. “

13 „Очигледно је да стари црнац представља шамана неке афричке религије.“

14 „сведок времена“ 
calesero Melchor, luciendo sonrisa de dientes /.../“ ${ }^{15}$ (Carpentier 2001: 57). У наставку текста читамо:

/.../la vida no tenía encanto fuera de la presencia del calesero Melchor. Ni Dios, ni su padre, ni el obispo dorado de las procesiones del Corpus, eran tan importantes como Melchor. Melchor venía de muy lejos. Era nieto de príncipes vencidos. En su reino había elefantes, hipopótamos, tigres y jirafas. (Carpentier 2001: 58) ${ }^{16}$

Карпентјер на тај начин индиректно наглашава Мелхиорово афричко порекло. Над овим одељком Вилијам Луис (Luis 1991: 155) се пита није ли црнац са почетка приче заправо Мелхиор (Melchor), из далеке земље побеђених принчева. Ипак, питање је зашто се Мелхиор јавља као лик тек у Марсијаловом детињству. Претходно смо већ навели да се старац црнац јавља у улози сведока времена. Са друге стране, познато је да одрастао човек окован нормама и правилима није свестан протока времена, што можемо видети и у примеру из приповетке:

Una noche, después de mucho beber y marearse /.../ Marcial tuvo la sensación extraña de que los relojes de la casa daban las cinco, luego las cuatro y media, luego las cuatro, luego las tres y media/.../Fue una impresión fugaz, que no dejó la menor huella en su espíritu, poco llevado, ahora, a la meditación. ${ }^{17}$ (Carpentier 2001: 51)

15 „Дошло му је да плаче, али у том тренутку се појавио кочијаш Мелхиор, показујући кроз осмех блиставе зубе/.../“ (Карпентјер 2011: 135)

16 „/../живот није био нимало занимљив без присуства кочијаша Мелхиора. Ни бог, ни његов отац, ни епископ у позлаћеној одори за време ускршње процесије, нису били тако значајни као Мелхиор. Мелхиор је био пореклом из далека. Био је нећак побеђених принчева. У његовом краљевству било је слонова, тигрова, нилских коња и жирафа. /.../ Мелхиор је знао песмице које су се лако училе јер речи нису имале никакво значење и много су се понављале.“ (Карпентјер 2011: 136-137)

17 „Једне ноћи, после много пића и ошамућености /.../ Марсијал је добио чудно осећање као да сатови избијају пет, затим пола пет, па четири, затим пола четири. /.../ Био је то краткотрајан утисак који је у његовој глави, неспремној за медитације, није оставио ни најмањи траг.“" (Карпентјер 2011: 130) 
Карпентјер овим објашњава да одрастао човек тек у полусвесном стању примећује проток времена, и то не било каквог времена, него оног које тече уназад. Насупрот томе, живот детета се заснива на чулним утисцима и због тога је оно свесно времена. Могли бисмо чак рећи да једино што дете поседује а одрастао човек нема, јесте управо време. Из овог разлога запажамо блискост Мелхиора са малим Марсијалом кога учи песмицама налик бајалици и питамо се да ли то Мелхиор открива малом Марсијалу магију којом се време враћа, исту ону коју видимо на почетку дела када почиње да прави чудне покрете руком и време почиње да се враћа у прошлост. Јасно је да дете може осетити време, али чак и тада дете наликује одраслом човеку по томе што мисли да је оно господар времена: „Comenzaron a jugar al ajedrez. Melchor era caballo. Él, era Rey"18 (Carpentier 2001: 57).

\section{4. Мотив regressus ad uterum}

Стари црнац у „Путу ка семену“, дакле, наликује шаману неке непознате религије и његово враћање времена представља магијски ритуал. Мирче Елијаде (Eliade 2004: 85) објашњава значај повратка уназад у религијама неразвијених друштава и повратак у време зачећа назива regressus ad uterum. О особинама и улози ове врсте повратка Елијаде говори следеће: „U svim se tim slučajevima regressus ad uterum provodi u cilju porađanja novog člana u novi oblik življenja ili preporođaja. S gledišta strukture, povratak u matericu odnosi se na vraćanje Svemira u "kaotično“ ili embrionalno stanje. Pretporođajna tmina odnosi se na Noć prije Stvaranja i na mrak inicijacijske kolibe“ (Eliade 2004: 87). Дакле, аутор „Пута ка семену“ се не враћа у време у коме је Марсијал зачет, већ његове тежње путују много даље, по Елијадеовом мишљењу (Eliade 2004: 88), чак до Ноћи пре Стварања света. На питање зашто Карпентјера занима повратак у време када свет још није био створен, Елијаде (Eliade 2004: 88-89) нуди одговор: ради излечења, односно коначног ослобођења, „izlečenja čoveka od

18 „Почеше да играју шаха. Мелхиор је био коњ. Он је био краљ.“ (Карпентјер 2011: 135) 
boli postojanja u Vremenu“. Читав овај процес садржи више фаза: „Riječ je o tome da se krene od nekog preciznog trenutka koji je najbliži sadašnjem, te da se vrijeme prijeđe unatrag /.../ kako bi se stiglo ad originem, kada je prvo postojanje, 'pojavivši se' u svijetu, pokrenulo Vrijeme. Time dolazi do spajanja tog paradoksalnog trenutka izvan kojega Vrijeme nije postojalo, budući da se ništa nije pokazivalo“ (Eliade 2004: 93). На основу овога закључујемо да Карпентјер тежи избављењу од времена које за човека представља највећи терет. Ослободивши се времена човек би могао да досегне вечност. Према томе, Карпентјер не враћа време узалуд јер његово путовање ка семену има циљ: прећи у вечност.

Постоји нешто магично у повратку коренима које модерно друштво није спремно да прихвати јер се труди да живи у садашњости, или речима Елијадеа (Eliade 2004: 37) „Povratak podrijetlu /.../predstavlja iskustvo od bitnog značaja za arhaična društva“. Чини се, међутим, да Карпентјер у свом делу сједињује модерно и архаично друштво означавајући себе као универзалног представника људске врсте. „Poznavanje podrijetla i povijesti stvari kao primjera, pruža neku vrstu magične moći nad stvarima. /.../“ (Eliade 2004: 97). Ова моћ задобија се једноставним чином, само треба „сјетити се“, како каже Елијаде (Eliade 2004: 97), онога што је било на самом почетку пре постања света. Вечност се, дакле, не достиже размишљањем да је све од нас почело, већ да је и пре нас постојао читав један универзум цивилизација и древних култура који нам је у облику мита оставио у наслеђе сећање на Почетак.

\section{5. Прошлост, садашњост, будућност или циклично кретање}

„Пут ка семену“ представља пут у прошлост који Карпентјер трасира техником приповедања уназад. Међутим, питамо се какав је ауторов однос према садашњости и будућности, те какво је време изван живота које Карпентјер испитује повратком у мајчину утробу.

Када смо говорили о структури приповетке, споменули смо да је повратак у прошлост приказан од II до XII 
поглавља, док у I и XIII поглављу аутор приказује садашњи тренутак. Треба истаћи да иако између првог и последњег поглавља следи читав низ реверзибилних догађаја, Карпентјер директно повезује ова два поглавља тако што се радња првог поглавља наставља у последњем. На крају првог поглавља налазе се следећи редови: „Dieron las cinco. Las cornisas y entablamentos se desploblaron. Sólo quedaron escaleras de mano, preparando el salto del día siguiente. /.../ Un marco de puerta se erguía aún, en lo alto, con tablas de sombras suspendidas de sus bisagras desorientadas" 19 (Carpentier 2001: 46). Затим, занемаривши следећих једанаест поглавља, у последњем одељку видимо речи: „Cuando los obreros vinieron con el día para proseguir la demolición, encontraron el trabajo acabado. Alguien se había llevado la estatua de Ceres, vendida la víspera a un anticuario“ ${ }^{20}$ (Carpentier 2001: 62). Иако је читава прошлост једног маркиза стала између ова два поглавља, стижемо до закључка да време није престало да тече ка будућности (González Hernández 2017: 12). На овај начин Карпентјер организује време приповетке у два смера: од садашњости ка будућности и од садашњости ка прошлости (видети слику 1).

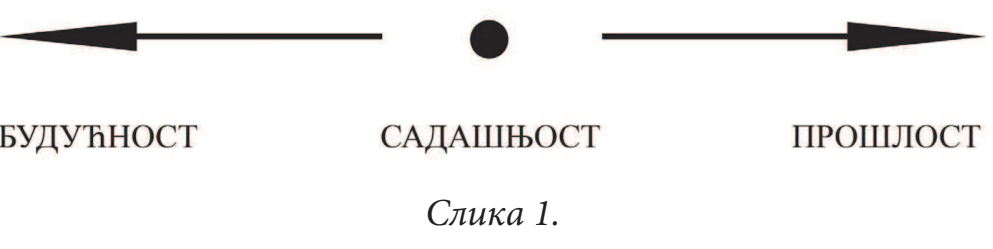

Међутим, ова једноставна шема не може у потпуности приказати сложено кретање времена у „Путу ка семену“. Наиме, у XIII поглављу у коме аутор радњу поново премешта у садашњост која се креће ка будућности, читамо

19 „Одзвонило је пет. Корнише и симсови се срушише. Само су остале мердевине, припремајући скок наредног дана. /.../ Један оквир од врата још увек се горе уздизао, док су даске тмине висиле на његовим дезорјентисаним шаркама." (Карпентјер 2011: 125-126)

20 „Када су се радници сутрадан вратили да наставе са рушењем, наишли су на завршен посао. Неко је однео статуу Церес, продату синоћ једном антиквару.“ (Карпентјер 2011: 140) 
следеће: „Pero nadie prestaba atención al relato, porque el sol viajaba de oriente a occidente, y las horas que crecen a la derecha de los relojes deben alargarse por la pereza, ya que son las que más seguramente llevan a la muerte“ ${ }^{21}$ (Carpentier 2001: 62). Карпентјер нам, дакле, поручује да пут ка будућности води у смрт или, другим речима, у небиће. Са друге стране, и прошлост нас води ка истом циљу, враћању у време када човек још није постао човек, већ обитава у облику небића. Намеће се питање да ли се будућност и прошлост срећу у још једној тачки, али овог пута ван времена (видети слику 2).

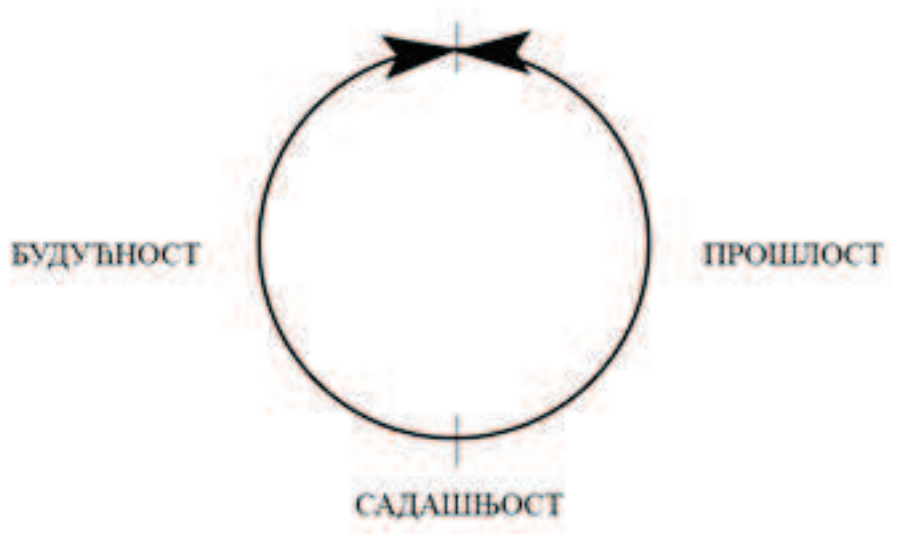

Слика 2.

Ако имамо у виду да структура дела открива да се у овиру садашњег времена (I и XIII поглавље) налази прошлост (II-XII поглавље), долазимо до закључка да ове две временске равни не само да се сусрећу у једној тачки, већ се и преплићу. На слици 3. добићемо најприближнији приказ времена који преноси његову комплексност.

21 „Али нико није обраћао пажњу на причу јер је сунце ишло са истока на запад, и часови који расту на десној страни часовника треба да се продуже лењошћу, јер су они ти што најсигурније воде у смрт.“ (Карпентјер 2011: 140) 


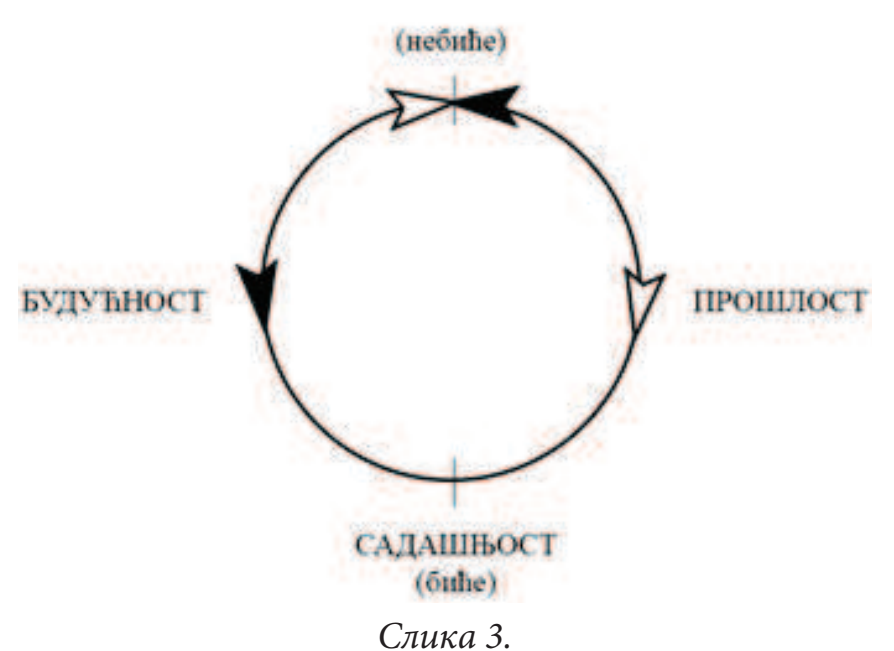

На основу оваквог приказа увиђамо да ће се будућност у неком тренутку претворити у прошлост, као и да ће оно што је у прошлости достићи тренутак кад ће се звати будућност. Дакле, пошавши од претпоставке о реверзибилности времена, долазимо до закључка да је кретање времена заправо циклично. Румеларе (Rommelaere 2009: 59) наглашава да је Карпентјерова намера била да споји прошлост, садашњост и будућност у једно трајање.

Карпентјер брише границе између временских категорија чинећи кретање времена цикличним, али не и уједначеним, јер даљом анализом „Пута ка семену“ увиђамо да се време креће различитим брзинама. У првом поглављу наилазимо на речи: „Para la casa mondada el crepúsculo llegaba más pronto"22 (Carpentier 2001: 46). Аутор нам на овај начин наговештава да како се ствари, предмети, па и сами људи приближавају свом крају тј. смрти, тако време протиче све брже и брже. Питамо се, ипак, да ли је тако само када се ближимо смрти, или време протиче брже и након повратка у мајчину утробу. Одговор налазимо у XII поглављу: „Entonces cerró los ojos /.../ y penetró en un cuerpo caliente, húmedo, lleno de tinieblas, que moría. /.../ Pero ahora el tiempo corrió más

22 „За очерупану кућу вече је брже долазило“ (Карпентјер 2011: 126) 
pronto, adelgazando sus últimas horas. Los minutos sonaban a glissando de naipes bajo el pulgar de un jugador" ${ }^{23}$ (Carpentier 2001: 61). Након преображавања у небиће време се толико брзо обрће да је тешко опазити његово кретање, те се чини да је оно непомично и статично. Николсон (Nicholson 1983: 19) овакво кретање пореди са обртањем точка који када се креће великом брзином изгледа као да се не помера. Чини се да је Карпентјер враћајући се у прошлост док се истовремено кретао ка будућности, успео у њиховом пресеку да пронађе вечност. Ако је заиста тако, онда је Карпентјер коначно решио мистерију преласка из времена у вечност.

\section{6. Крај времена и нови живот у вечности}

Карпентјер нам не нуди само нове погледе на концепт времена, већ нам даје и одговоре на питања шта је вечност и како је достићи. „Пут ка семену“ приказан је кроз биографију појединца која симболише човекову самоћу на животном путу. Поред тога, „Пут ка семену“ има такозвани отворени крај, па је самим тим време у њему ослобођено од сваке врсте коначног одређења. Карпентјер препушта читаоцима тумачење концепта времена које је створио, и на тај начин се временске перспективе умногостручују. У „Путу ка семену“ представљена је људска тежња ка ослобађању од Времена и достизању вечности. Управо је регресивно време послужило као метафора за ослобађање човека и његову припрему за нови живот у облику небића које обитава у вечности. Да би се створили услови за нестанак Времена, цео свет се мора вратити на почетак, у време пре Постања, како каже Елијаде (Eliade 2004), у тренутак када Свет и Време још нису били створени. На основу овога закључујемо да „do pravog početka ne može doći bez stvarnog kraja“ (Eliade 2004: 79).

Карпентјер нам је кроз више примера у „Путу ка семену“ наговестио да човек од рођења до смрти заправо умире јер

23 „Онда је затворио очи /.../ и утиснуо се у једно топло, влажно и мрачно тело које је умирало. /.../ Али, сада је време брже летело скраћујући његове последње часове. Минути су одзвањали као пребирање карата испод коцкарског палца.“ (Карпентјер 2011: 139) 
се тако човек удаљава од Постања, од првобитног времена и Вечности. Насупрот томе, што је човек ближи Постању, то је све живљи, те закључујемо да је истински живот само онај који води путем ка семену. Напоменули смо и да се време креће све брже и брже како се човеков живот приближава небићу. Свако биће, дакле, тежи оном првобитном стању безвремености и вечности у коме бива ослобођено од свега земаљског. Напослетку се питамо да ли ово дело представља крај Времена или нови живот у Вечности. Алехо Карпентјер, међутим, мотив времена у свом делу није учинио једнодимензионалним. Он је кроз „Пут ка семену“ сјединио и повезао крај Времена са новим животом у Вечности.

„Пут ка семену“ подсећа на најдубље животне заблуде људи. Карпентјерово дело нам приказује сличност између рођења и смрти и преиспитује нас да ли смо живели или пак умирали док смо мислили да имамо времена. Аутор нам још објашњава да окови времена везују човека и оптерећују га, и показује нам разлог због чега је то тако: Човек је заборавио да је некад био слободно биће, да је пре настанка Времена био вечан. Према Карпентјеру, највећа трагедија за човека је заборављање сопствених корена. Због тога он креће на пут ка семену, ка добу пре Постања, када су сви људи били једно и када је то једно чинило цео свет. На неки начин, време је казна за човека јер је некадашње безвремено биће кажњено пролазношћу и константним пропадањем. Човек је изгубио вечност и кажњен је временитошћу јер је одлучио да буде сам, јер се у доба пре стварања Времена одвојио од заједнице и живота у хармонији. Човек који је изабрао самоћу, изгубио је истовремено и вечност и љубав, а живот је претворио у смрт. Карпентјер у „Путу ка семену“ кроз поништавање овоземаљског живота враћа човеку вечну природу, а Октавио Пас (Octavio Paz 2007: 195) овом процесу, поредећи га са љубавним чином, даје потпуно нову димензију: „Creación y destrucción se funden en el acto amoroso: y durante una fracción de segundo el hombre entrevé un estado más perfecto. “" ${ }^{24}$

24 „Стварање и уништавање се сједињују у чин љубави: а у току једног делића секунде човек назире савршенство.“ 
Алехо Карпентјер нам је открио да само привидно живимо у историјском времену, јер нас је чудно понављање историје заробило у магичном временском кругу из кога се можемо избавити тек када се сетимо наших корена и вратимо у нашу безвремену и вечну природу.

\section{ИЗВОРИ И ЛИТЕРАТУРА}

Altenberg, Tilmann. "Alejo Carpentier o las trampas de la memoria: Tiempo regresivo y referencias al pasado en "Viaje a la semilla". Iberoromania, 64.2 (2007): 67-86. ResearchGate. Web. 07.06.2018.

Carpentier, Alejo. "Viaje a la semilla". Guerra del tiempo y otros relatos. Madrid: Alianza Editorial, 2001.

Eliade, Mircea. Aspekti mita. Prevela Nataša Pejović. Zagreb: Demetra, 2004.

González Hernández, Carla. "El tratamiento del tiempo en Guerra del tiempo y otros relatos de Alejo Carpentier". Trabajo de fin de grado inédito. Universidad de la Laguna, 2017. Universidad de la Laguna. Web. 01.06.2017.

Luis, William. "Historia, Naturaleza y Memoria en Viaje a La Semilla”. Revista Iberoamericana, 57.154 (1991): 151-160. Revista Iberoamericana. Web. 08.06.2018.

Martín Jiménez, Alfonso. "La estructura temporal de "Viaje a la semilla" de Alejo Carpentier". Draco: $\quad$ Revista de literatura Española, 5-6 (1994): 311-326. UVaDoc. Web. 01.06.2018.

Nicholson, Irene. Mexican and Central American Mythology. Middlesex: Newnes Books, 1983. Archive. Web. 25.05.2018.

Paz, Octavio. El laberinto de la soledad. Madrid: Fondo de cultura económica, 2007.

Rommelaere, Joke. "Mitología y tiempo mítico en Guerra del tiempo y otros relatos de Alejo Carpentier". Tesis de máster inédita. Univesidad Gent, 2009. Ghent University library. Web. 07.06.2018.

Карелин, Рафаил. Умеће умираюа или умейности живљењь. Будва: Манастир Подмаине, 2014.

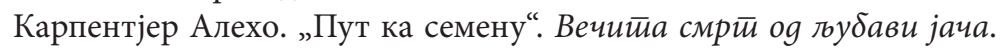
Бојана Ковачевић Петровић (ур.). Превео Радоје Татић. Београд: Танеси, 2011. 125-140. 


\title{
Jovana Vulić
}

\author{
THE TIME AND ETERNITY IN “JOURNEY \\ BACK TO THE SOURCE” BY ALEJO CARPENTIER
}

\section{Resume}

Alejo Carpentier, a Cuban writer of the twentieth century, in his work "Journey back to the source" deals with the universal topic of time and eternity through the prism of a mythological context. The process of a reverse narrative presents human life from the moment of death until the moment of conception. Carpentier examines the struggle between linear historical and mythological cyclical times and raises the question of the existence of time categories of the past, the present and the future. Carpentier's "Journey back to the source" shows us the path to eternity that begins after the end of the mortal time, at the moment when a man remembers his roots. 